\title{
Desperately Seeking Impact
}

DOI:

10.1080/17411912.2011.596397

\section{Document Version}

Accepted author manuscript

Link to publication record in Manchester Research Explorer

\section{Citation for published version (APA):}

Bithell, C. (2011). Desperately Seeking Impact. Ethnomusicology Forum, 20(2), 233-244.

https://doi.org/10.1080/17411912.2011.596397

\section{Published in:}

Ethnomusicology Forum

\section{Citing this paper}

Please note that where the full-text provided on Manchester Research Explorer is the Author Accepted Manuscript or Proof version this may differ from the final Published version. If citing, it is advised that you check and use the publisher's definitive version.

\section{General rights}

Copyright and moral rights for the publications made accessible in the Research Explorer are retained by the authors and/or other copyright owners and it is a condition of accessing publications that users recognise and abide by the legal requirements associated with these rights.

\section{Takedown policy}

If you believe that this document breaches copyright please refer to the University of Manchester's Takedown Procedures [http://man.ac.uk/04Y6Bo] or contact uml.scholarlycommunications@manchester.ac.uk providing relevant details, so we can investigate your claim.

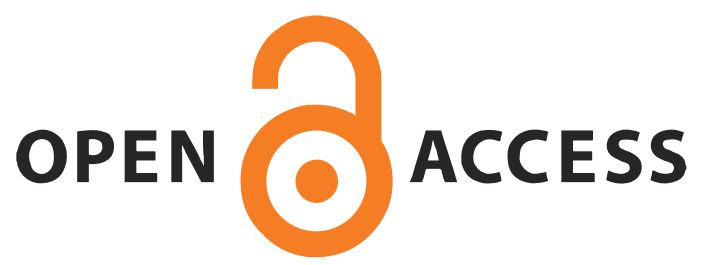




\section{Desperately Seeking Impact}

\section{Caroline Bithell \\ University of Manchester, UK}

NOTE: This is a post-print (Author's Accepted Manuscript) for:

Bithell, Caroline, 'Desperately Seeking Impact'. Ethnomusicology Forum, vol. 20/2 (2011): 233-244. DOI: $10.1080 / 17411912.2011 .596397$

Poet $^{1}$

Impact is an action in need of an object.

When does the impact happen?

It might be harsh and sudden,

A taut palm on the skin of a drum or on bare flesh,

A screech of brakes as metal meets metal.

Or it might be soft as silk,

Fleeting as sunlight in winter

Or a half-remembered tune from a half-remembered dream.

It might take years to bear fruit.

How do I impact you?

How do you impact me?

Where does the impact happen?

What counts? To whom? Why? Who cares?

\section{Politician $^{2}$}

We all know that music has impact, and we may concede that your work has impact, but how are you going to measure it? Just try explaining it to us in language we understand!

\footnotetext{
${ }^{1}$ See Figure 1. In the original presentation, I donned a series of hats to indicate the character position at each point of my talk.

${ }^{2}$ See Figure 2.
} 


\section{Academic}

Who 'owns' impact?

Do I have to patent it?

How do we apportion impact? (How do we apportion blame?)

Do we have to claim it for ourselves?

Can impact be co-authored?

Can impact be plagiarised?

Over what exactly might I have dominion?

What responsibilities might be mine?

How much impact do I not make?

Do I have to have impact? Why me?

Perhaps I'm just interfering?

Perhaps I'm colonising all over again.

\section{Ethnomusicologist ${ }^{3}$}

The notion of impact in ethnomusicology is, of course, nothing new. We've been talking about it for a while now, in the company of more nuanced terms that are more bottom-up than top-down - engagement, advocacy, activism. The special themed issue of the British Journal of Ethnomusicology, entitled Fieldwork Impact (Cooley 2003), grew out of the British Forum for Ethnomusicology's annual conference at Sheffield in 2000, where we considered the impact - both positive and negative - we may have on the places, communities and traditions that we engage with in our fieldwork. Henry Stobart's edited volume The New (Ethno)musicologies, which started life with our 2001 one-day conference at Royal Holloway College, is awash with references to 'engagement' and

\footnotetext{
3 See Figure 3.
} 
'applied ethnomusicology'. 'Impact' is in there too. Tina K. Ramnarine refers in her contribution to a surge in 'engaged ethnomusicology' - which she equates with 'applied ethnomusicology' - and concludes by emphasising that the relevance of music scholarship 'includes its impact on musical performance and education beyond the academy' (2008:93).

Anthony Seeger, in his Charles Seeger lecture delivered at the Society for Ethnomusicology's $50^{\text {th }}$ anniversary conference in Atlanta in 2005, and subsequently published in the journal Ethnomusicology with the title 'Lost Lineages and Neglected Peers: Ethnomusicologists Outside Academia', spoke urgently of the need to combine a reflective theoretical life with a practical one. He reminded us that the academy is more comfortable with, and therefore pushes us towards, the theory - privileging print publications over recordings and multi-media, refereed journals over more popular outlets; and that the institutions we work for haven't known how to measure public outreach or political involvement. But his message was clear: 'It is important not to confuse the strategy of institution building with the definition of our discipline ... I recommend that we think about what we can contribute through the knowledge we are privileged to have had the opportunity to learn' $(2006: 221,223)$. Seeger paid tribute to Alan Lomax as 'a model ... of a combination of applied and theoretical ethnomusicology' (ibid.:218), and to Pete and Mike Seeger, both of whom had such farreaching influence and impact outside any institutional framework or affiliation. To this list we might now add Charlie Gillett, Lucy Durán, Andy Kershaw, Jan Fairley, Simon Broughton, The Rough Guide to World Music and Songlines magazine. (This is why I am an ethnomusicologist.)

Figure 1 Poet. Source: Chloe Grant, 2011.

Figure 2 Politician. Source: Chloe Grant, 2011.

Figure 3 Ethnomusicologist. Source: Chloe Grant, 2011.

\footnotetext{
${ }^{4}$ Jonathan Stock, in his contribution to The New (Ethno)musicologies, defines applied ethnomusicology as 'work with a primary intended output of musical or social benefits, rather than the increase of original scholarly knowledge' (2008:202).
} 


\section{Many Musicologists}

It's often what they learn about the impact of music on people's lives, as much as 'the music itself', that attracts students to our courses. Through our lectures, they learn about the world. We offer ways into the history and politics of countries about which - after 14 years in full-time education - they know remarkably little. (This is why I am an ethnomusicologist.)

Many of our students are most excited by topics related to censorship, civil rights, protest movements and struggles of one kind or another - in Afghanistan, Zimbabwe, South Africa, Algeria, Chile. They lap up Freemuse reports, as if relieved finally to have confirmation that music is about far more than practice rooms and concert stages - that it is often, quite literally, a matter of life and death; that it can change the destinies of individuals and nations. ${ }^{5}$ Music suddenly makes sense as part of an ethic of inclusivity and tolerance, a way of giving voice to the voiceless. Henry Stobart, in The New (Ethno)musicologies, reports that a survey he conducted among his students revealed that they 'connected ethnomusicology with a sense of social awareness and political engagement' (2008:4). One of the first questions I'm asked when I offer a new module is: 'Will it be political?' Before I know what's happened they've booked a flight to Cuba.

The courses some of us teach in the field of arts management, the culture industries or community music open eyes in different ways, bringing the impact of music - and the notion of music as a participatory art - closer to home. Here our students are often drawn to outreach and development projects. They explore the underbelly of the city with its less salubrious venues and more colourful clientele; they befriend buskers, get involved in hospital radio, play string quartets in care homes and gamelan in prisons. For many of them, this is again an answer to a question and the beginning of a future.

Here, the impact of music itself, and of how we teach about music, is clear as day.

\section{Politician}

But unfortunately, that kind of impact doesn't count. It's behind closed doors. An ivory tower is an ivory tower. Haven't you heard of knowledge transfer? You need to get out more.

\footnotetext{
5 Freemuse - The World Forum on Music and Censorship, established following the 1st World Conference on Music and Censorship held in Copenhagen in November 1998 - is an independent international organisation that advocates freedom of expression for musicians and composers worldwide. See www.freemuse.org (last accessed 30 May 2011).
} 


\section{Ethnomusicologist}

As it happens I get out quite a lot. The challenge is to talk about what I find in ways you understand. We're talking qualitative data here. We write thick descriptions. We could learn to speak Mandelsonian or the new coalition dialect but we're not sure if we want to.

\section{Caroline}

So how do we talk about the impact of our engagement with the wider community in terms that are fair and meaningful to all concerned - not neatly linear, not a one-way flow? How do we engage with the impact of other people's work, whether deliberate (they set out to have impact) or coincidental (we see the impact that they themselves may not be aware of)? What status is accorded to our reports of the impact of non-academic activists or enthusiasts in the field? How does this translate into, or prove its descent from, 'excellent' research?

My current project on the natural voice, community choirs and world song offers ample scope for pondering such questions. The natural voice movement as a whole has proven impact in several respects - self-empowerment, personal well-being and transformation, community building, intercultural understanding. The movement is founded on the principle that 'singing is everyone's birthright' - a 'natural' part of human life. ${ }^{6}$ Natural-voice style community choirs are open-access: there are no auditions and members don't need to be able to read music since everything is taught by ear. In bypassing musical literacy, the movement embraces many of those who are excluded from other kinds of musical activity, while challenging established hierarchies and assumptions about musical competency. It also provides a home for singers whose goals are primarily interpersonal and experiential rather than driven by ambitions of stardom. Much of what participants report about their involvement in this scene is testimony to music's potential for facilitating community and interpersonal understanding, while the lives of individuals suffering a variety of ills have been quite literally turned around after they have found their way to 'the choir'.

Songs from Georgia, Bosnia, Cameroon, Zimbabwe, Hawai'i or the Isle of Barra offer themselves as suitable material because they come from oral traditions. In learning

\footnotetext{
${ }^{6}$ See www.naturalvoice.net (last accessed 30 May 2011).
} 
the songs, participants are often prompted to find out more about the places they come from. Some go on to travel to the source, on tours organised by groups such as Village Harmony, to learn directly from local singers, to experience the songs in their natural environment, to see and hear how they are a part of social practices and life ways. ${ }^{7}$ Some choirs seek out meetings with 'others' closer to home, for example, by gaining access to 'reception centres' where those denied permanent asylum in the UK await deportation.

Many of those who have derived personal benefit from their natural voice involvement also have impact on other lives through their singing activities. Every September, an 800-strong choir made up of amateur singers from across the country performs a set of 'world songs' as part of the Thames Festival to raise money for WaterAid projects in Africa and India. The brainchild of singer and actress Helen Chadwick, Sing for Water grew out of her involvement with Georgian singing, and its inaugural programme in 2001 was dedicated entirely to Georgian songs. ${ }^{8}$ When Russian forces invaded Georgia in the summer of 2008, singers in the UK, North America, Australia, France and elsewhere gathered in public places at an agreed time to sing Georgian songs as an expression of solidarity and a means of drawing attention to Georgia's plight, and video clips of these performances immediately found their way to Georgia. In London, a Georgian supra was held on the Battersea Barge to raise money for refugees facing the winter in tents on the outskirts of Tbilisi and to help rebuild the university and library in Gori. ${ }^{9}$

Madge Bray, after a high-flying career working with victims of child abuse, found her way to Georgia after initially attending a workshop in Scotland that was erroneously advertised (thanks to a typographical error) as a day of Gregorian chant. When she brought a severely disabled child back to Edinburgh for specialist surgery, she enrolled him in a local primary school. Without a word of English to smooth his way, and with barely an unbroken bone in his body, he promptly beat all the boys in the class at armwrestling and started teaching them Georgian songs. In October 2010, a group of nine and ten year olds from that school travelled to Tbilisi, where they sang Georgian songs on

\footnotetext{
7 Village Harmony, an association based in Vermont (USA), acts as 'an umbrella for a range of choral music, world music and harmony singing activities'. Its initiatives include an annual programme of overseas summer camps. See www.villageharmony.org (last accessed 30 May 2011).

${ }^{8}$ See www.wateraid.org/uk/get_involved/community_groups/sing_for_water/default.asp (last accessed 30 May 2011).

${ }^{9}$ The Georgian supra (lit. 'table-cloth') is a lavish ceremonial feast presided over by a tamada (toastmaster or master of ceremonies) and is viewed as the ultimate embodiment of the principles of generosity and hospitality that are central to Georgian national identity. It features a series of heartfelt toasts, in ritual order, punctuated by exuberant singing.
} 
stage at the International Symposium on Traditional Polyphony before heading up country to visit the orphanage where their new friend lives. Georgian TV was flooded with images of diminutive girls in kilts singing Georgian songs and suddenly everyone in Georgia knew the story of their abused friend and his struggling orphanage, which Madge - through the charities Ecologia Youth Trust and Braveheart Georgia - also supports directly with the profits from the Georgian workshops she now organises in the UK. ${ }^{10}$ Meanwhile, back in Edinburgh, one of the Scottish boys says: 'Ever since I've met Datuna, school things have changed ... last year ... we wouldn't [sing in class] cos we were too shy. Now we like music cos ... we sing in the class and all that in front of everybody. And I just think everything's changed. I think we've been happier ever since we've met Datuna'. ${ }^{11}$

If Edisher Garakandize, the Georgian ethnomusicologist largely responsible for the introduction of Georgian songs to the UK in the mid-1990s, ${ }^{12}$ were alive today and based at a UK institution, he could surely sweep the board at the impact equivalent of the BAFTA awards. ${ }^{13}$ Or ... would he need an audit trail?

I play my part in all of this. In my interactions with these networks of amateur singers and seekers, I contribute 'scholarship', personal experience of 'being there', musical expertise, teaching skills, the stories behind the songs. I alert people to relevant and accessible sources. I alert them to one another. I run my own choirs and workshops. But I didn't invent the idea. And some of the movement's more prominent activists are able to dedicate far more time and energy than I to the kind of work we might describe in the terms of the impact agenda. I tell these stories. I translate them as best as can.

Figure 4 Lucy Durán, Caroline Bithell and Stephen Cottrell on the Impact Roundtable at the 2010 One-Day Conference of the British Forum for Ethnomusicology. Source: Laudan Nooshin, 2010.

\footnotetext{
10 See www.ecologia.org.uk (last accessed 30 May 2011) and www.braveheartgeorgia.org (last accessed 30 May 2011).

11 Thinking About Datuna, 2010. Copy of video documentary provided by Madge Bray and Thornlie School.

12 Edisher first visited the UK in 1994 at the invitation of the Centre for Performance Research, then based in Cardiff, together with his colleague Joseph Jordania. He returned many times in the years that followed to lead Georgian singing workshops in different parts of the country. At the time of his death in 1998, he was working on the book 99 Georgian Songs, conceived as a workbook 'for singers in the west' and later published by Black Mountain Press (Garakanidze 2004).

${ }^{13}$ BAFTA, the British Academy for Film and Television Arts, is the UK's leading independent charity working with the film, TV and video games industries, whose remit is to 'support, develop and promote the art forms of the moving image, by identifying and rewarding excellence, inspiring practitioners and benefiting the public'. Its annual award ceremonies - the British equivalent of the Oscars - are hosted by the Royal Opera House and attract extensive media coverage.
} 


\section{Poet}

Some people have auras; others have audit trails and indicators.

Some indicators are robust and verifiable; others are merely anecdotal.

Sometimes it is like the wrong kind of snow.

Sometimes it is just business as usual.

\section{News Reporter}

Chaos hits the NHS as hospitals across the country struggle to cope with a particularly virulent outbreak of questionnaire fatigue, which, they say, they are ill-equipped to deal with. The virus is affecting people of all ages and from all walks of life but with regular concert-goers and museum visitors being among the hardest hit.

A research group from the University of Northwest Upper Ramsbottom has today announced its discovery of a new syndrome, audittrailitis, together with proposals for a comprehensive screening programme targeted at academics, who have been identified as those most at risk. Questions have been raised about the robustness of the research team's methodology and the admissibility of some of their data, with one critic who would have preferred to remain anonymous being caught on mic saying, 'Personally, I think it's all a load of old hat'.

\section{God}

Who has impact?

Who makes history?

\section{... and Pete Seeger (after Florence Reece)}

Which side are you on?

Figure 5 Impact Questionnaire. Your feedback is important to us. Tell us what YOU think! ${ }^{14}$

\footnotetext{
14 This questionnaire was distributed to participants following a second version of my 'paper' given at the University of Manchester, March 2011. The presentation on this occasion bore the subheading 'An Investigation into the Impact of Research Activity within the Subject of Music, Drama, Dance and the Performing Arts, and into the Impact of the Impact Agenda on the Physical, Spiritual and Economic Well-being of British Academics'. It featured additional contributions from my colleagues Susan Rutherford and Alice Bartlett.
} 


\section{DESPERATELY SEEKING IMPACT — AUDIENCE FEEDBACK}

If you require a copy of this questionnaire in large print or in any language under the sun, or would like it sent direct to your iPhone, all you have to do is ask.

I confirm that I am filling in this questionnaire with my consent.

I understand that, if I am filling it in with my own pen, this is entirely at my own risk.

I consent to my responses being included in future editions of your work.

In attributing direct quotes, I would like you to use:

My full name $\quad \square \quad$ My first name only $\quad \square \quad$ A pseudonym *

* To ensure that we do not misrepresent you with regard to your gender, ethnicity, religion or sexual orientation, all pseudonyms will be approved by the University Ethics Committee. If your real name is Ali or River, please help us by telling us a little more about yourself.

How would you describe the impact today's presentations has had on you?

Has today's presentation enhanced your understanding of impact? If so, in what way?

Do you now feel more positive about impact than you did at 9 o'clock this morning?

Was your decision to attend this event impacted in any way by the unfounded rumour about free alcohol?

As a result of attending today's presentation, are you more likely to:

Go to the theatre more often Yes No Maybe Prefer not

Attend research seminars more often

Be kind to animals and children

Cycle to work

Join a choir

Join the union

to say

Buy British eggs

Buy a hat

Drink more brandy

Stick your head in the sand

$\begin{array}{llll}\square & \square & \square & \square \\ \square & \square & \square & \square \\ \square & \square & \square & \square \\ \square & \square & \square & \square \\ \square & \square & \square & \square \\ \square & \square & \square & \square \\ \square & \square & \square & \square \\ \square & \square & \square & \square \\ \square & \square & \square & \square \\ \square & \square & \square & \square\end{array}$


Believe in God

Go to Cuba

Invite us to your next party

As a result of attending today's presentation, are you less likely to:

Yes No Maybe Prefer not

Go to the theatre more often

to say

Break other people's windows

Start a fight outside a pub

Rob a bank

Run off with someone else's wife

Drop litter

Swear in public

$\begin{array}{llll}\square & \square & \square & \square \\ \square & \square & \square & \square \\ \square & \square & \square & \square \\ \square & \square & \square & \square \\ \square & \square & \square & \square \\ \square & \square & \square & \square \\ \square & \square & \square & \square \\ \square & \square & \square & \square \\ \square & \square & \square & \square\end{array}$

Invite us to your next party

If we were to disseminate this research further, which of the following publications do you think would have the most impact?

$\square$ The Guardian

$\square$ The Sun

$\square$ The Baltic Journal of Experimental Theatre*

$\square$ Wikipedia

$\square$ The Horrible Histories series

$\square$ The Beano

* peer-reviewed

If we were to give a public performance of this piece, which of the following venues do you think would be most suitable?

$\square$ The National Theatre

$\square$ The Frog and Bucket*

$\square$ The People's History Museum

$\square$ A soapbox on Hyde Park Corner

$\square$ Virgin Atlantic in-flight entertainment

$\square$ An undisclosed venue to be sent to your iPhone by coded text message

$\square$ A reconstruction of the Titanic

* Manchester's hottest comedy club

If we had charged for today's event, how much would you have been prepared to pay?

Would you recommend this event to your friends?

Yes $\square \quad$ No $\square \quad$ I don't have any friends

Would you recommend this event to your enemies?

Yes $\square \quad$ No $\square \quad$ I love my enemies so have included them under friends 
If at any time you wish to withdraw your contribution, please email us at: admin@impact.co.mars

If you have been disturbed by anything in today's presentation, please write to:

David Willetts, MP, The House of Commons, London

\section{References Cited}

Cooley, Timothy (ed.). 2003. Fieldwork Impact. Special issue of the British Journal of Ethnomusicology 12(1).

Garakanidze, Edisher, Joseph Jordania and Joan Mills. 2004. 99 Georgian Songs: A Collection of Traditional Folk, Church and Urban Songs from Georgia. Aberystwyth: Black Mountain Press.

Ramnarine, Tina K. 2008. 'Beyond the Academy'. In The New (Ethno)musicologies, edited by Henry Stobart, 83-94. Lanham, MA: Scarecrow Press.

Seeger, Anthony. 2006. 'Lost Lineages and Neglected Peers: Ethnomusicologists Outside Academia'. Ethnomusicology 50(2): 214-35.

Stobart, Henry. 2008. 'Introduction'. In The New (Ethno)musicologies, edited by Henry Stobart, 1-20. Lanham, MA: Scarecrow Press.

Stock, Jonathan P. J. 2008. 'New Directions in Ethnomusicology: Seven Themes Toward Disciplinary Renewal'. In The New (Ethno)musicologies, edited by Henry Stobart, 188-206. Lanham, MA: Scarecrow Press. 